\title{
The Analysis of Effectivity and Efficiency of Tax Collection from Hotels and Restaurants in Order to Increase the Original Regional Income (PAD) in Mataram
}

\author{
Rini Yuliandari, Taufik Chaidir, Hadi Mahmudi \\ Magister Program of Economic Science University of Mataram \\ Email: riniyuliandari95@gmail.com
}

Received: June 28, 2017; Accepted: September 10, 2017; Published: November 3, 2017

Permalink/DOI: http://dx.doi.org/10.17977/um002v9i22017p257

\begin{abstract}
This research aims to discover the effectivity, the efficiency, the performance as well as the contribution of tax collection from hotels and restaurants toward the Original Regional Income in Mataram from 2011 until 2016. The method used is a quantitative method for case study as the data collection. The result shows that the effectivity and efficiency of the tax collection from hotels and restaurants in Mataram are considered in the effective and efficient category. Meanwhile, the contribution of hotels and restaurants tax collection to the regional tax is $0,27 \%$ and $0,13 \%$ toward the Original Regional Income, thus, the hotel and restaurant taxes give a good contribution to the regional tax and original regional income in Mataram. In addition, the performance of hotels and restaurants tax is in a developing category.
\end{abstract}

Keywords: Effectivity, Efficiency, Performance, Hotel and Restaurant Tax, Original Regional Income (PAD)

JEL Classification: G31, H17

\section{INTRODUCTION}

Development is an effort to create prosperity and wealth for the citizen. Furthermore, economic development is defined as efforts to enhance the living standard of a nation that is measured by the high and the low-income Nile per capita (Irawan \& Suparmoko, 1995). Therefore, the result should be experienced by all of the citizens to upgrade physical and spiritual prosperity evenly. Development, however, depends on the Original Regional Income of all Indonesian, which means that it should be implemented evenly by all of the Indonesian not only in the burden of the development but also in the responsibility and also the result.

This research will discuss hotels and restaurants tax because they have the potential to contribute more to the regional economy. From the justice side, this tax is fair because upper groups tend to spend their income in Hotels and restaurants more than lower groups. Meanwhile, small business is not charged with tax (Devas, 1989). With the increasing number of hotels and restaurants, and they received attention from the local government, the government will ultimately obtain more tax revenue and levies, hence it is expected in accordance with the target revenue area. Regarding its territory, the study was held in Mataram based on the city being the center of the economic cycle.

The Regional Government in this case tries to increase and develop the construction of Hotels and Restaurants in order to enhance the regional income, to 
expand and broaden job opportunities, to push regional development, to increase citizen prosperity, and to enrich the national cultures while still keep protecting the religious values and defending the Nation personality. Moreover, this development is expected to boost the improvement, the introduction, and marketing of National products. Various efforts are carried out by the government of Mataram, such as providing good media and infrastructures. In the media field, for instance, some new hotels are built and the older ones are reconstructed as well as the facilities are upgraded. Tourism objects, caterings, and travels are upgraded too.

The positive growth of the economy in Mataram in the last few years gave big impacts toward the increasing of Original Regional Income (PAD) in Mataram. It can be seen from the development of the business climate in Mataram, such as the construction of hotels, restaurants, entertainments, and other types of business. This business climate, thus, becomes one of the sources to dig the potential of regional tax in Mataram. The efforts to increase the regional income through the intensification and extensification of regional tax and also fee is done by the Department of Income Office Region (Dispenda) in Mataram. Increasing the collection performance, perfecting, digging the potential and updating the database as well as processing the regional tax-management based on information and technology (IT) are done so that the performance target planned can be achieved optimally.

Hotels and restaurants tax are two types of regional tax with which the potential is decreasing as the attention shift to the supporting components like service and tourism sectors (Enggar et al., 2012; Lamia, 2015). Hotels and restaurants tax have an important role in the original regional income (PAD) (Khairunissa, 2011; Jannah et al., 2016). The existence of Hotels and Restaurants will increase Original regional income in Mataram. With the number of developing hotels and restaurants in Mataram, will the tax collection considered effective and efficient, and just how big is the contribution given by Hotels and restaurants tax to PAD in Mataram.

Research about Efficiency dan effectivity tax collection to improve Original Regional Income has previously been conducted by some researchers. Ida (2013) concluded that the level of effectivity of tax received from hotels and restaurants in Semarang from 2008 until 2012 faced fluctuation from year to year because some hotels were closed in 2010 to 2012. However, the realization of tax received from hotels and restaurants is still in very effective criteria.

The related researchers have been conducted previously. Pertiwi \& Purwati (2014) conducted a research about The Analysis of Restaurant Tax Potential in Wisata Anyer Serang Regency. From the calculation, the realization of tax received from the restaurant is only $33,4 \%$ from the amount of restaurant tax potential existing. By observing the proportion of potential in restaurant tax and its realization to the goal of restaurant tax determined by the Regional Government, it shows that the Regional Government did not calculate the potential existing in the expected decree and the tax potential excavation which has not been done yet. The effective calculation of restaurant tax in the region of Wisata Anyer was less than $100 \%$. It showed that the effectivity of restaurant tax was considered not effective yet. The variable of Restaurant tax has a significant impact toward the realization of tax received in the region of Wisata Anyer. Therefore, there was an obvious 
correlation between restaurant tax potential and the realization of restaurant tax received.

Julita (2015) conducted research about the Analysis of Effectivity and Efficiency Regional Income and Budget in Living Environment Agency in North Sumatra Province. From the result of the analysis and discussion, it can be inferred that based on the calculation effectivity ratio of the estimated income in 2009 and 2012, the performance of the North Sumatra Provincial Environment Agency (BLH-PROVSU) was very effective.

Yunanto (2010) researched about the Analysis of Potential, Tax Effort, Efficiency, Affectivity and Elasticity of Hotel Tax in Klaten Regency. Finding shows that the potential of Hotel tax in Klaten Regency is Rp.250.514.310,- on average. Meanwhile, the realization of the Hotel tax received in the same year is Rp.90.803.731,-or only 36,27\% of the potential. The Tax effort was the ratio between the Hotel tax received and PDRB is $0,00136 \%$. Efficiency showed that the ratio between collection fee and the realization is $7,67 \%$. The effectivity of tax collection from Hotel seen from the ratio between realization with the average target is $99,6 \%$, whereas from the comparison between tax realization and average potential is $36,27 \%$, the elasticity of Hotel tax is 1,24 or higher than 1 , which means it is elastic. The calculation pointed toward positive so that there was a tendency for improvement of Hotel tax in the future. The government of Klaten Regency should make policies and action to increase Hotel tax by intensification and extensification of Hotel tax, simplifying the tax regulation, and giving strong punishment to those who disobey the policy.

\section{METHOD}

It is a quantitative research method. The location of research is in Mataram, and data collection method used is case study method, while the data collection in this research is Hotel and Restaurant Tax data, Local Taxes, and Local Original Revenue period 2011 - 2016. The technique of collecting data is through primary and secondary data collection. Primary data collection is data collection by interview, while secondary data are obtained based on documentation report done periodically by Revenue Department of Mataram. Variables used in this study are local taxes, hotel and restaurant taxes, and local revenue (PAD). The operational definitions of the variables used in this study are Hotel and Restaurant Tax, Regional Tax, Local Revenue, Efficiency, Effectiveness, and Performance. Techniques and analytical tools used in this study are a descriptive technique that describes the data, and then the method used is the method of ratio analysis and performance matrix.

\section{RESULT AND DISCUSSION Local Tax Growth Rate}

Local Tax Growth Rate - the realization growth which consists of Hotel and Restaurant Taxes has increased. The highest tax realization growth occurred in 2014 , in which a target of IDR 83.080.000,00 was able to achieve the realization of IDR 91,749,599,728.00. It is due that all components of local taxes are able to achieve realization, except the tax of swallow bird's nest, and in the aforementioned years, the average target of local taxes and the realization continued to increase. This shows that the local governments are able to realize the increase in local taxes 
each year above the target average, which means for the last six years that the realization of local taxes exceeds the established tax target.

The realization growth of Hotel and Restaurant taxes in Mataram from 2011 to 2016 increased. In detail, the highest realization growth of hotel tax occurred in 2016 in which the target of IDR 20.000.000.000,00 was able to reach realization which was equal to IDR 22.122.172.262,94, whilst the highest realization growth of restaurant tax occurred in 2013 in which the target of IDR 7.800.000.000,00 was able to reach the realization of IDR 9,577,267,010,00. Therefore, over the last 6 years, the hotel and restaurant taxes are able to achieve greater realization than the set targets.

\section{Analysis of Effectivity}

Effectivity indicates the rate of success or failure to achieve the goals; thus, the effectivity measures only an output(s). The hotel tax effectiveness rate is measured using target data and realization. The calculation of the effectivity of hotel tax of Mataram from 2011 to 2016 experienced a significant level because its effectivity shows above $100 \%$ which means that it was very effective. Meanwhile, the effectivity rate of restaurant taxes which is also measured using target data and realization shows exactly the same trend that is very effective.

\section{Analysis of Efficiency}

The efficiency level is measured using input data compared to the output. There are three outputs which are measured; the wage collection, the cost of SKPD and transportation costs. The determination of operational costs is difficult because the operational costs incurred by DPPKAD are not only issued to collect hotel and restaurant taxes but also to levy other taxes or those issued in the form of joint costs in connection therewith. To get the operational cost calculated based on the cost actually incurred relating to the collection of hotel and restaurant tax that is the printing cost of Local Tax Assessment (SKPD) of Hotel Tax and transportation cost of delivery of SKPD which the amount of each year is adjusted.

The hotel and restaurant tax rate applied in accordance with the applicable law is $5 \%$ of realized realization. This collection is called an incentive. This incentive division is adjusted to their respective positions. The Regional Tax Assessment letter for the hotel each year varies depending on the tax object found per year. This Local Tax Assessment Letter is made in book form, in which in one book there are 150 sheets, and the price of the book is adjusted to the number of printed books. the cost of printing increases every year, so the costs incurred for this printing costs will increase. While the cost of transportation is required for delivery SKPD only. So only a small amount of fee, because this hotel tax is a type of self-assertion tax where the hotel tax is deposited directly to the tax office by the taxpayer. Transportation costs are only issued for pick-up or delivery of the SKPD. Each year, transportation costs are typically increased due to an increase in prices and costs every year.

Tax collection of both hotels and restaurants in Mataram city in the last 6 years (2011 - 2016) fluctuated, but the differences are not too significant. The highest ratio for hotel text collection occurred in 2011 which amounted to $54.6 \%$, and the lowest occurred in the year 2016 that is equal to $52.0 \%$. Meanwhile, the highest ratio for restaurant text collection occurred in 2012 and 2015 at $54.1 \%$, and 
the lowest occurred in 2016 of $52.9 \%$. Looking at the efficiency of ratios per year and then compared to the efficiency ratios in the previous years show that relatively the tax collection of both hotels and restaurant in Mataram has been efficient.

\section{Analysis of Performance}

Performance in 2011 is not calculated since it is used as the base year in determining tax growth for the coming year. The growth of hotel and restaurant taxes from 2012 to 2016 is at a number greater than one, while for the proportion is below 1 . In accordance with the performance matrix formula, the performance of hotel and restaurant tax over the aforementioned years is in the developing category.

\section{Analysis of Hotel and Restaurant Tax Contributions}

Hotel and Restaurant Tax is one of the Regional Government Revenue (PAD) of Mataram City with which the local government is able to receive additional income that is through levies at hotels and restaurants in Mataram. Additionally, it contributes quite well to the Original Revenue. Source: Mataram Regional Office of Revenue (data processed).

Hotel and Restaurant Tax Contribution to Regional Taxes in Mataram for five years generally increased, although the increase was fluctuating. In 2011, Hotel and Restaurant Taxes contributed 0.28, whilst in 2012 it rose to 0.30 . Over the next two years, its contribution declined, it was 0.25 in 2013 and 0.24 in 2014. However, it again rose to 0.25 in 2015 and 0.32 in 2016. While on the one hand, the Hotel and Restaurant Tax Contribution against the Original Regional Income (PAD) including small enough with a fluctuating percentage. It can be seen, however, that the starting point was 0.15 in 2011 and it then decreased by 0.14 in 2012. It remained constant at the same number, 0.14, in 2013. Unfortunately, in the next two years, 2014 and 2015, it declined. However, in 2016, its contribution increased by 0.14 . Overall, hotel and restaurant taxes have an additional percentage of benefits with other receipts, and they are able to contribute reasonably well to the Original Income.

\section{CONCLUSION}

In accordance with the findings, it can be inferred that: (1) The effectivity rate of hotel and restaurant tax collection for six years (2011-2015) has been effective. Overall, the first hypothesis which states that hotel and restaurant tax collection have been effectively implemented is acceptable; (2) The efficiency rate of hotel and restaurant tax collection during the six years (from 2011 to 2016) is in an efficient category. (3) After calculating the contribution of hotel and restaurant tax to local tax and Local Revenue, it can be obtained as follows: $0,27 \%$ for local tax and $0,13 \%$ for PAD. It can be stated that the hotel and restaurant taxes are considered able to contribute quite well to local taxes and Local Revenue. (4) The condition of hotel and restaurant tax within six years is included in the developing category. From the calculation matrix of hotel and restaurant tax performance, it can be concluded that from 2011 to 2016 its performance is quite good and the category is growing. This is because at that time it has been in the reverse of the collection system.

Based on the conclusions of the above research findings, it is suggested that: (1) the results show that although the contribution of hotel and restaurant tax receipts is not as one of the largest contributors to local revenue, the hotel and 
restaurant taxes are quite contributing. It is; therefore, the hotels and restaurants need to be intensified through digging up new revenue sources and increasing revenue from the previous years and existing revenue sources. (2) Local Revenue Offices (Dispenda) needs to improve both organizational and administrative work systems by conducting comparative studies to other areas considered more advanced. Besides that, the Regional Office of Revenue also needs to improve the mental quality and capacity of its employees acting as the driving force in government organizations. (3) The government of Mataram city should propose a draft local tax on new the hotel and restaurant taxes. After the draft passed into law, the government need to socialize with the community in regards to the importance of the meaning of development funding sources for regional progress.

\section{REFERENCES}

Devas, N. (1989). Keuangan Pemerintah Daerah di Indonesia. Jakarta: Penerbit Universitas Indonesia.

Dispenda. (2015). Target dan Realisasi PAD di Kota Mataram (2015): Mataram.

Enggar, D. P., Rahayu, S., \& Wahyudi, I. (2012). Analisis Efisiensi dan Efektivitas Penerimaan Pajak Daerah Propinsi Jambi (Studi Pada Dinas Pendapatan Daerah Propinsi Jambi). Jurnal Penelitian Universitas Jambi: Seri Humaniora, 13(1), 69-82.

Ida, J. (2013). Efektifitas dan Kontribusi Penerimaan Pajak Hotel dan Pajak Restoran terhadap Pendapatan Asli Daerah (PAD) kota Semarang. Universitas Dian Nuswantoro Semarang.

Irawan \& Suparmoko. (1995). Ekonomika Pembangunan. Yogyakarta: BPFE.

Jannah, H.E.L.EN., Suyadi, I., \& Utami, H.N. (2016). Kontribusi Pajak Daerah Terhadap Pendapatan Asli Daerah (Studi Pada Dinas Pendapatan Kabupaten Mojokerto). Jurnal Perpajakan (JEJAK), 10(1), 1-8.

Julastiana, Y., \& Suartana, I. W. (2012). Analisis Efisiensi dan Efektivitas Penerimaan Pendapatan Asli Daerah Kabupaten Klungkung. E-Journal Akuntansi, 2(1), 1-17.

Julita. (2015). Analisis Efektivitas dan Efisiensi Anggaran Pendapatan dan Belanja pada Badan Lingkungan Hidup Provinsi Sumatera Utara. Kumpulan Jurnal Dosen Universitas Muhammadiyah Sumatera Utara, 10(2).

Khairunissa. (2011). Pajak Hotel dan Pajak Restoran Sebagai Sumber Pendapatan Asli Daerah (PAD). Jurnal Perencaan Wilayah dan Kota, 22(3), 227-244.

Lamia, A. (2015). Analisis Efektifitas Dan Kontribusi Pemungutan Pajak Restoran, Pajak Reklame, Dan Pajak Penerangan Jalan Pada Pendapatan Asli Daerah Kabupaten Minahasa Utara. Jurnal Berkala Ilmiah Efisiensi, 15(5).

Mangkoesoebroto, G. (2001). Ekonomi publik. Yogyakarta: BPFE.

Pertiwi, D. I., \& Purwanti, E. Y. (2014). Analisis Potensi Pajak Restoran di Kawasan Wisata Anyer Kabupaten Serang. Diponegoro Journal of Economics, 3(1), 2-8.

Sukirno, S. (1982). Pengantar Teori Mikroekonomi. Jakarta: Lembaga Penerbit Fakultas Ekonomi Universitas Indonesia.

Yunanto, L. (2010). Analisis Potensi, Upaya Pajak, Efisiensi, Efektivitas dan Elastisitas Pajak Hotel di Kabupaten Klaten (Doctoral dissertation, Universitas Sebelas Maret). 